\title{
The effect of temperature on leaf decomposition and diversity of associated aquatic hyphomycetes depends on the substrate
}

\author{
Ana Lúcia GONÇALVES*, Manuel A.S. GRAÇA, Cristina CANHOTO \\ IMAR-CMA, Department of Life Sciences, University of Coimbra, 3001-401 Coimbra, Portugal
}

\section{A R T I C L E I N F O}

\section{Article history:}

Received 7 April 2013

Revision received 1 July 2013

Accepted 3 July 2013

Available online 8 September 2013

Corresponding editor:

Felix Bärlocher

Keywords:

Fungal diversity

Litter quality

Stream ecosystems

Temperature

\begin{abstract}
A B S T R A C T
We examine the relative importance of substrate quality and temperature in the establishment of aquatic hyphomycete assemblages and in their ability to decompose leaves. We used leaves of alder (Alnus glutinosa) and oak (Quercus robur) and we tested four temperatures $\left(5^{\circ}, 10^{\circ}, 15^{\circ}\right.$ and $\left.20^{\circ} \mathrm{C}\right)$. Differences in decomposition rates and fungal assemblages were higher substrata than across temperatures. In both species, decomposition efficiency measured as the ratio of decay rate to fungal biomass, was greater at higher temperatures. Oak leaves were colonized by fewer aquatic hyphomycete species than was alder. Decomposition rates of oak increased with temperature but that of alder was not affected. We conclude that the substratum is a key driver of aquatic hyphomycete assemblages and can attenuate the effects of temperature differences on litter decomposition.
\end{abstract}

๑ 2013 Elsevier Ltd and The British Mycological Society. All rights reserved.

\section{Introduction}

Small woodland streams account for most of the total length of a river and are characteristically heterotrophic, given their dependence on terrestrial plant litter as a source of energy and carbon (Webster and Benfield, 1986; Abelho, 2001). Leaf litter decomposition in such streams is a key ecosystem-level process carried out by a varied assemblage of microbes (fungi and bacteria) and invertebrates (Gessner et al., 1999, 2010). The activity, diversity and productivity of aquatic hyphomycetes, a dominant group in early stages of leaf litter degradation, depends on the physico-chemical characteristics of the leaves and intraspecific variability in leaf traits, as well as being influenced by environmental factors (Gessner et al.,
1999, 2007; Suberkropp, 2001; Baldy et al., 2002; Lecerf et al., 2005; Lecerf and Chauvet, 2008). It is generally accepted that microbial-mediated decomposition is retarded in low quality substrata (i.e. low nutrients and high lignin concentrations) while soft, highly nutritious leaves (e.g. N and P rich) tend to stimulate decomposition (Gessner and Chauvet, 1994; Canhoto and Graça, 1996; Ferreira et al., 2006).

Among the various environmental factors that have been identified as important regulators of stream ecosystem processes, temperature is of paramount relevance due to its role as a modulator of biological processes (e.g. Friberg et al., 2009; Woodward et al., 2010; Bergfur and Friberg, 2012). Evidence from terrestrial systems suggests that the ratio of labile to recalcitrant substances of a substratum may affect the

\footnotetext{
* Corresponding author. IMAR - Marine and Environmental Research Centre (IMAR-CMA), Department of Life Sciences, University of Coimbra, P.O. Box 3046, 3001-401 Coimbra, Portugal. Tel.: +351 239855 760x401; fax: +351 239823603.

E-mail address: aga@ci.uc.pt (A.L. Gonçalves).

1754-5048/\$ - see front matter ( 2013 Elsevier Ltd and The British Mycological Society. All rights reserved. http://dx.doi.org/10.1016/j.funeco.2013.07.002
} 
temperature sensitivity of its decomposition (Conant et al., 2008, 2011), while a study in freshwater indicates that higher temperatures may overrule the importance of intrinsic differences in leaf characteristics on microbial-mediated decomposition (Fernandes et al., 2012). Experiments with European alder leaves (high-nutrient content) revealed that raising the temperature lead to an increase in microbialmediated decomposition (e.g. Fernandes et al., 2009, 2012; Ferreira and Chauvet, 2011a,b; Geraldes et al., 2012), in spite of a general reduction of fungal diversity and the consequent changes in the structure of fungal communities (Bärlocher et al., 2008; Fernandes et al., 2009, 2012; Ferreira and Chauvet, 2011a). It seems plausible that temperature changes may result in species replacement (probably related to fungal species-specific thermal physiological limits) with the overall ecological functions remaining intact. Furthermore, the effects of temperature on fungal performance are not straightforward: oscillations could causes differ compared with continuous gradients, since exposure to extreme values may inhibit fungal activity (Rajashekhar and Kaveriappa, 2000; Bergfur and Friberg, 2012; Bärlocher et al., 2013), promoting significant changes in litter decomposition with cascading effects throughout stream food webs.

We used a microcosm experiment to assess leaf mass loss and associated aquatic hyphomycete assemblages of alder (Alnus glutinosa; high quality) and oak (Quercus robur; low quality) leaves across a temperature range from 5 to $20{ }^{\circ} \mathrm{C}$. Both species have been commonly used as testspecies in decomposition experiments (e.g. Gessner and Chauvet, 1994; Ferreira et al., 2006; Gulis et al., 2006; Lecerf et al., 2007). We hypothesize that deviation from the prevailing stream temperature from which the aquatic hyphomycete assemblages were obtained will affect fungal diversity, which in turn will affect both the activity and decomposition of the 2 leaf species accordingly. Differences across temperatures are expected to be more striking on the more recalcitrant leaf.

\section{Methodology}

\section{Microcosms and experimental setup}

Alder (A. glutinosa) and oak (Q. robur) leaves were collected from the forest floor immediately after fall and air-dried in the dark at room temperature. To stimulate the loss of secondary compounds that usually retard fungal colonization in streams, leaves were leached for $48 \mathrm{hr}$ in aerated distilled water in the lab and oven-dried $\left(60{ }^{\circ} \mathrm{C} ; 48 \mathrm{hr}\right.$ ). Portions of leaves were ground up and analyzed for phosphorus, nitrogen, carbon, total polyphenolics (\% leaf dry mass; as described in Graça et al., 2005) and lignin (\% leaf dry mass; as described in Goering and Van Soest, 1970). Additionally, initial toughness was measured as penetrance (Graça et al., 2005), i.e. the required mass (g of water in a container) to push a $1 \mathrm{~mm}$ diameter metal shaft through the leaf disc.

The remaining leaves were used to obtain pairs of $12 \mathrm{~mm}$ diameter leaf discs, which were punched out symmetrically in relation to the main leaf vein with a cork borer. Groups of 20 discs from each species were oven-dried $\left(105^{\circ} \mathrm{C}\right.$; $48 \mathrm{hr}$ ), pre- weighed ( $\pm 0.1 \mathrm{mg}$ ), rehydrated by spraying with distilled water and enclosed in $6 \times 6 \mathrm{~cm}$ fine mesh bags $(0.5 \mathrm{~mm})$. In each bag, two groups of five discs (each one with known symmetrical pairs) were separately marked with nylon lines to allow identification in subsequent experiments (see below).

A total of 192 bags, each with 20 leaf discs (96 with alder and 96 with oak) were tied to nylon ropes and immersed in the Candal stream (a 2nd order stream located in Serra da Lousã at $617 \mathrm{~m}$ asl; Central Portugal; W $40^{\circ} 4^{\prime} 44^{\prime \prime} \mathrm{N}$ and $\left.8^{\circ} 12^{\prime} 10^{\prime \prime} \mathrm{W}\right)$ to allow microbial colonization for $7 \mathrm{~d}$. During the incubation, the water was $90 \%$ saturated with oxygen, the temperature was $9{ }^{\circ} \mathrm{C}$ (Jenway 9200 oxygen meter; Jenway, UK), the $\mathrm{pH}$ was 6.6 (Jenway 3150; Jenway, UK) and the conductivity reached $25.7 \mu \mathrm{Sm}^{-1}$ (WTW LF 330; WTW, Germany) (mean of two measurements on days 1 and 4). Stream water samples were transported to the laboratory in a cooler, filtered (glass fiber filter, $0.7 \mu \mathrm{m}$ pore size, Millipore APFF) and frozen at $-18^{\circ} \mathrm{C}$ for determination of cations and anions by ion chromatography (Dionex DX-120, Sunnyvale, California, USA) and soluble reactive phosphorus (SRP) concentration (Allan and Castillo, 2007). Stream values for nitrate, ammonia, sulfate, nitrite and phosphate SRP were: $0.13 \mathrm{mg} \mathrm{l}^{-1}, 0.96 \mathrm{mg} \mathrm{l}^{-1}, 1.48 \mathrm{mg} \mathrm{l}^{-1}$, $<100 \mu \mathrm{g} \mathrm{l} \mathrm{l}^{-1}$ and $45.33 \mu \mathrm{g} \mathrm{l^{-1 }}$, respectively. Additional stream water samples were collected, filtered as described above and autoclaved $\left(120^{\circ} \mathrm{C}, 1 \mathrm{hr}\right.$ ) for microcosm assays (see below). After stream incubation, all the bags were brought to the laboratory and the leaf discs rinsed with deionized water. From the 20 discs in each bag, one of the marked sets of five discs was used as a control to account for mass losses in the stream and to determine initial mass for subsequent laboratory experiments (see below); the corresponding symmetrical set was further immersed in the microcosm along with the other 10 discs from each bag. These 15 leaf discs from each replicate were placed in sterilized $100 \mathrm{ml}$ Erlenmeyer flasks with $40 \mathrm{ml}$ of sterile stream water. Batches of 48 microcosms (24 for each leaf species) were exposed to temperatures of $5,10,15$ or $20^{\circ} \mathrm{C}$, which encompass the annual temperature range of local streams.

The microcosms were incubated on shakers (120 rpm) under a $12 \mathrm{hr}$ light: $12 \mathrm{hr}$ dark photoperiod for $56 \mathrm{~d}$. Stream water was replaced every $2 \mathrm{~d}$ and spore suspensions were saved and combined to determine the total spore production and fungal diversity from each microcosm. After 7, 21, 35 and $56 \mathrm{~d}$, six replicates of each treatment were sacrificed to estimate leaf mass loss, microbial respiration and fungal biomass.

\section{Mass loss}

Leaf discs (control and exposed in microcosms) were ovendried (48 hr at $105{ }^{\circ} \mathrm{C}$ ), weighed $( \pm 0.1 \mathrm{mg})$, ashed $(5 \mathrm{hr}$ at $550{ }^{\circ} \mathrm{C}$ ) and reweighed to obtain ash free dry mass remaining (AFDMr). Mass loss was estimated as the \% difference between the dry mass of the discs not exposed and the discs exposed in the microcosms for $56 \mathrm{~d}$.

\section{Microbial respiration}

One set of five leaf discs from each microcosm was used to determine leaf associated microbial respiration. This was done 
by incubating the five leaf discs of each microcosm in $3 \mathrm{ml}$ respiration chambers in a Strathkelvin 929 respiration system (Glasgow, UK). Measurements were taken at the same temperature as the microcosms of origin (i.e. $5,10,15$ or $20^{\circ} \mathrm{C}$ ). The oxygen consumed during the experiment $\left(\mathrm{O}_{2}\right)$ was extrapolated to the entire incubation period (after 7, 21, 35 and $56 \mathrm{~d}$ ) by linear fitting (Matlab 7.6, Mathworks Company, Massachusetts, USA), to obtain the respiration rates as a function of time. The total amount of $\mathrm{O}_{2}$ consumed is the integral of this function. The standard error (SE) of the integral was determined using the standard theory of statistical error propagation from the fitted parameter errors (Tellinghuisen, 2001). The results were expressed in terms of the total carbon (C; $\mathrm{mg}$ ) released.

\section{Fungal biomass}

On each sampling date, we determined ergosterol content (as a proxy of fungal biomass; Gessner and Chauvet, 1993; Young, 1995) in a subset of five randomly chosen leaf discs from each microcosm. Leaf discs were freeze-dried, weighed, suspended in $2 \mathrm{ml}$ of methanol and treated with $0.5 \mathrm{ml}$ of $2 \mathrm{M}$ aqueous sodium hydroxide, heated in a microwave oven (1 min; $2450 \mathrm{MHz}$ and $750 \mathrm{~W}$ ), and the ergosterol was extracted with pentane (ca. $6 \mathrm{ml}$ ). The pentane was evaporated to dryness in a sand bath, at $55^{\circ} \mathrm{C}$, and the ergosterol was redissolved in $1 \mathrm{ml}$ of methanol. Ergosterol concentration was quantified by high performance liquid chromatography (HPLC) using a Merck LiChroCART 250-4 (LiChrospher 100) RP-18 column by measuring absorbance at $282 \mathrm{~nm}$ (Young, 1995). The ergosterol was converted into fungal biomass using a conversion factor of $5.5 \mu \mathrm{g}$ ergosterol $\mathrm{mg}^{-1}$ fungal dry mass (Gessner and Chauvet, 1993) and the results were expressed as mg fungal biomass $\mathrm{g}^{-1} \mathrm{DM}$.

\section{Aquatic hyphomycete sporulation}

Every second day, when the microcosm water was renewed, the conidial suspensions from the six microcosms to be sacrificed at $56 \mathrm{~d}$ were transferred into six $1.5 \mathrm{l}$ bottles and preserved with $2 \mathrm{ml}$ of $37 \%$ formalin. At the end of the experiment, the conidial suspensions were mixed with $2 \mathrm{ml}$ of Triton X - 100 solution (0.5\%), an aliquot was filtered (Millipore SMWP, $5 \mu \mathrm{m}$ pore size) and the retained spores stained with $0.05 \%$ cotton blue in lactic acid (60\%). Conidia were identified and counted under a compound microscope at $250 \times$ (Graça et al., 2005). Results were expressed as the total number of conidia microcosm ${ }^{-1}$.

\section{Statistical analysis}

Differences between alder and oak leaves in terms of chemical and physical parameters were assessed by t-tests. Decay rates ( $k$ ) for each species and temperature were calculated by linear regression of the logarithm $(\mathrm{ln})$ of the remaining mass over time, and taking the slope as the decomposition coefficient $(k)$ (Graça et al., 2005). Comparisons among temperatures in each leaf species were done by ANCOVA, with temperature as a categorical variable and time as the continuous variable, followed by Tukey's HSD.
Significant differences of respiration measurements were evaluated by confidence limits, which were provided by each temperature fit (Matlab 7.6, Mathworks Company, Massachusetts, USA). Peaks of fungal biomass, total number of conidia and total species richness per microcosm were compared among temperatures by one-way ANOVAs, followed by Tukey's HSD.

Fungal assemblages at different temperatures in each leaf species were compared by a non-metric Multidimensional Scaling (MDS), based on Bray Curtis similarity index of log $(\mathrm{x}+1)$ transformed conidial abundance data, and a cluster analysis was overlaid (PRIMER v6; Clarke and Gorley, 2001). An analysis of similarity (one-way ANOSIM) was also performed to test the similarity among temperature treatments to each leaf species. Conidial abundance was used to determine Shannon's diversity index (PRIMER v6) of the aquatic hyphomycete communities colonizing both leaf species at different temperatures, and compared by one-way ANOVAs (followed by Tukey's HSD), within each substratum, among temperatures. Additionally, for visual clarity, we combined all the conidial abundance data (from alder and oak leaves) in the same non-metric Multidimensional Scaling (MDS), followed by an analysis of similarity (two-way ANOSIM), with the temperature and leaf species as factors. When necessary, data were $\ln$ transformed to achieve normality and homoscedasticity and all analyses were performed with STATISTICA 7 (Zar, 1999).

\section{Results}

\section{Initial litter quality}

The initial values in alder and oak leaves did not differ significantly in terms of $\mathrm{P}(0.11 \pm 0.02 \%$ vs $0.05 \pm 0.02 \%$; mean $\pm \mathrm{SE}$; $t$ test $(6)=1.871, P=0.111), C(53.5 \pm 0.5 \%$ vs $58.1 \pm 2.0 \%$; $t$ test $(4)=2.316, P=0.081)$ and lignin concentrations ( $42.1 \pm 0.4 \%$ vs $41.5 \pm 0.3 \%$; $t$ test $(6)=1.150, P=0.294)$. However, alder had higher $\mathrm{N}$ concentrations $(3.70 \pm 0.10 \%$ vs $1.00 \pm 0.03 \%$; t test $(4)=21.535, P<0.0001)$ and about half of the total polyphenolic compounds of oak $(6.8 \pm 0.2$ vs $12.9 \pm 0.9 \%$; t test $(4)=6.801, P<0.001)$. Toughness was approximately twice as high in oak as in alder $(45.6 \pm 2.7 \mathrm{~g}$ vs $81.4 \pm 5.2$ g; $t$ test $(4)=6.241, P<0.001)$.

\section{Leaf decomposition and microbial respiration}

Decomposition rates of alder did not differ among temperatures $\left(k=0.0 \quad 120-0.0144 \mathrm{~d}^{-1}\right.$; ANCOVA, $F_{3,91}=2.081$, $P=0.108$; Fig 1A). The same was observed with the total respired carbon (Fig 1B; Table 1). Temperature affected decomposition of oak $\left(k=0.004-0.007 \mathrm{~d}^{-1}\right.$; ANCOVA, $\left.F_{3,90}=5.696, P=0.001\right)$, with higher rates at $20^{\circ} \mathrm{C}$ than at 5 and $10^{\circ} \mathrm{C}$ (Tukey's test, $\mathrm{P}<0.009$; Fig $\left.1 \mathrm{~A}\right)$. Respired carbon peaked at 10 and $15^{\circ} \mathrm{C}$ (Fig 1B).

\section{Fungal biomass}

The maximum fungal biomass associated with oak did not differ between temperatures (one-way ANOVA, $F_{3,18}=0.073$, 

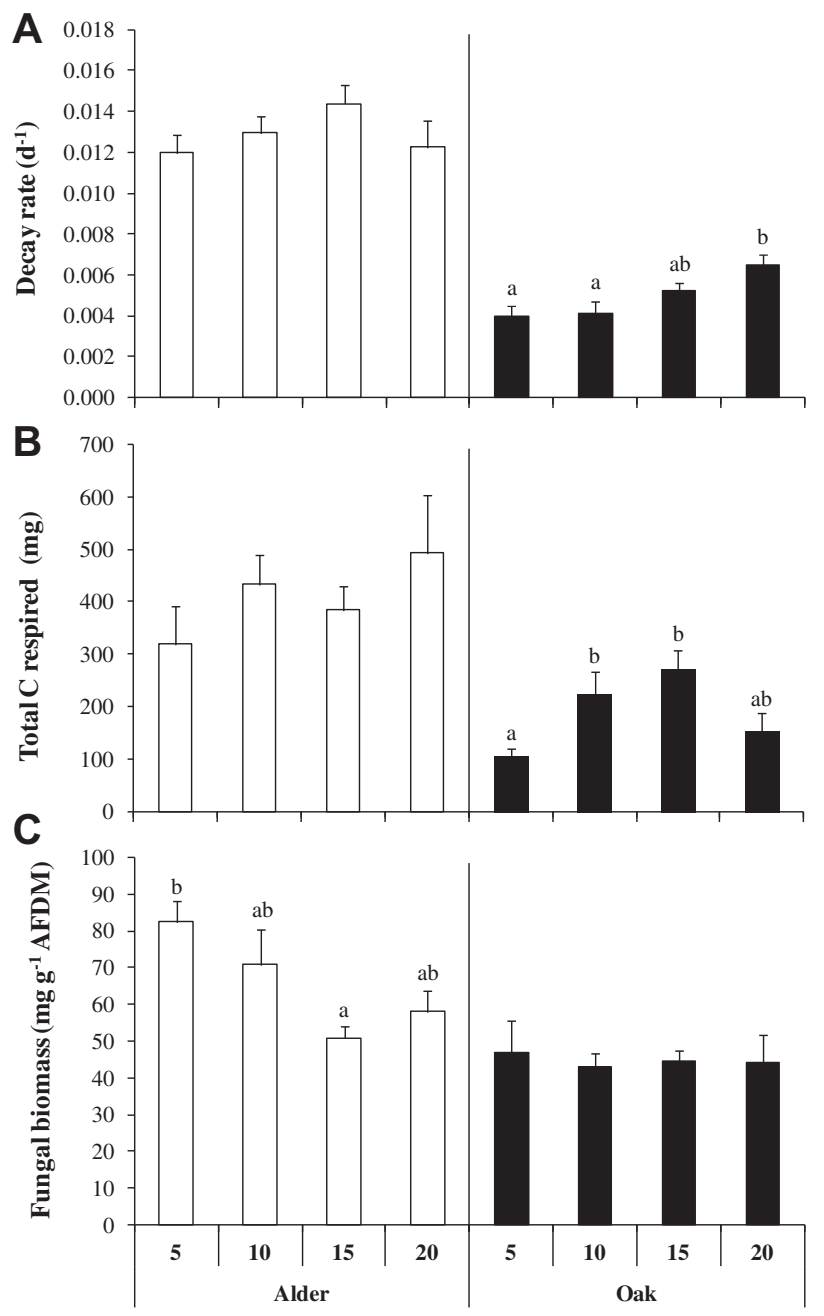

Temperature $\left({ }^{\circ} \mathbf{C}\right)$

Fig 1 - (A) Decay rate $\left(\mathrm{g} \mathrm{d}^{-1}\right)$, (B) total carbon respired and (C) fungal biomass peaks of alder and oak leaf discs incubated in microcosms for $56 \mathrm{~d}$ at $5,10,15$ and $20{ }^{\circ} \mathrm{C}$ (mean \pm SE; in a: $n=24$; in b: $n=20$; in c: $n=6$ ). No letters indicate absence of differences within the same leaf species.

$P=0.974$; Fig $1 C$ ) while temperature affected fungal biomass in alder (the peak of fungal biomass tended to decrease with the temperature gradient; one-way ANOVA, $F_{3,18}=3.433$, $\mathrm{P}=0.049$ ), with the lowest biomass at $15{ }^{\circ} \mathrm{C}$ (Tukey's test, $P>0.047$; Fig 1C).

\section{Sporulation rates and fungal communities}

In alder, the total number of conidia produced was higher at $10{ }^{\circ} \mathrm{C}(\sim 1.3$ million of conidia) than at other temperatures (one-way ANOVA, $F_{3,20}=12.222, P<0.001$; Tukey's test, $P<0.004$; Fig 2A). The total number of aquatic hyphomycete species was also higher at $5-10{ }^{\circ} \mathrm{C}(8-10$ species) and lower at $20^{\circ} \mathrm{C}$ (one-way ANOVA, $F_{3,20}=30.055$, $P<0.001$; Tukey's test, $P<0.024$; Fig $2 B)$; the same was observed for diversity $\mathrm{H}^{\prime}$ (one-way ANOVA, $F_{3,20}=32.035$,
Table 1 - Mean and confidence limits (CL) of total carbon released, provided by the integral of the respiration rate as a function of time at each temperature, for alder and oak leaf discs incubated in microcosms for $56 \mathrm{~d}$ at $5,10,15$ and $20^{\circ} \mathrm{C}$ (mean $\left.\pm \mathrm{SE} ; \boldsymbol{n}=\mathbf{2 0}\right)$

\begin{tabular}{lcc} 
& Temperature $\left({ }^{\circ} \mathrm{C}\right)$ & Mean with $95 \%$ CL \\
\hline Alder & 5 & $319(178-460)$ \\
& 10 & $432(320-545)$ \\
& 15 & $384(296-472)$ \\
Oak & 20 & $492(273-711)$ \\
& 5 & $105(78-133)$ \\
& 10 & $224(138-309)$ \\
& 15 & $272(205-339)$ \\
& 20 & $151(81-221)$ \\
\hline
\end{tabular}
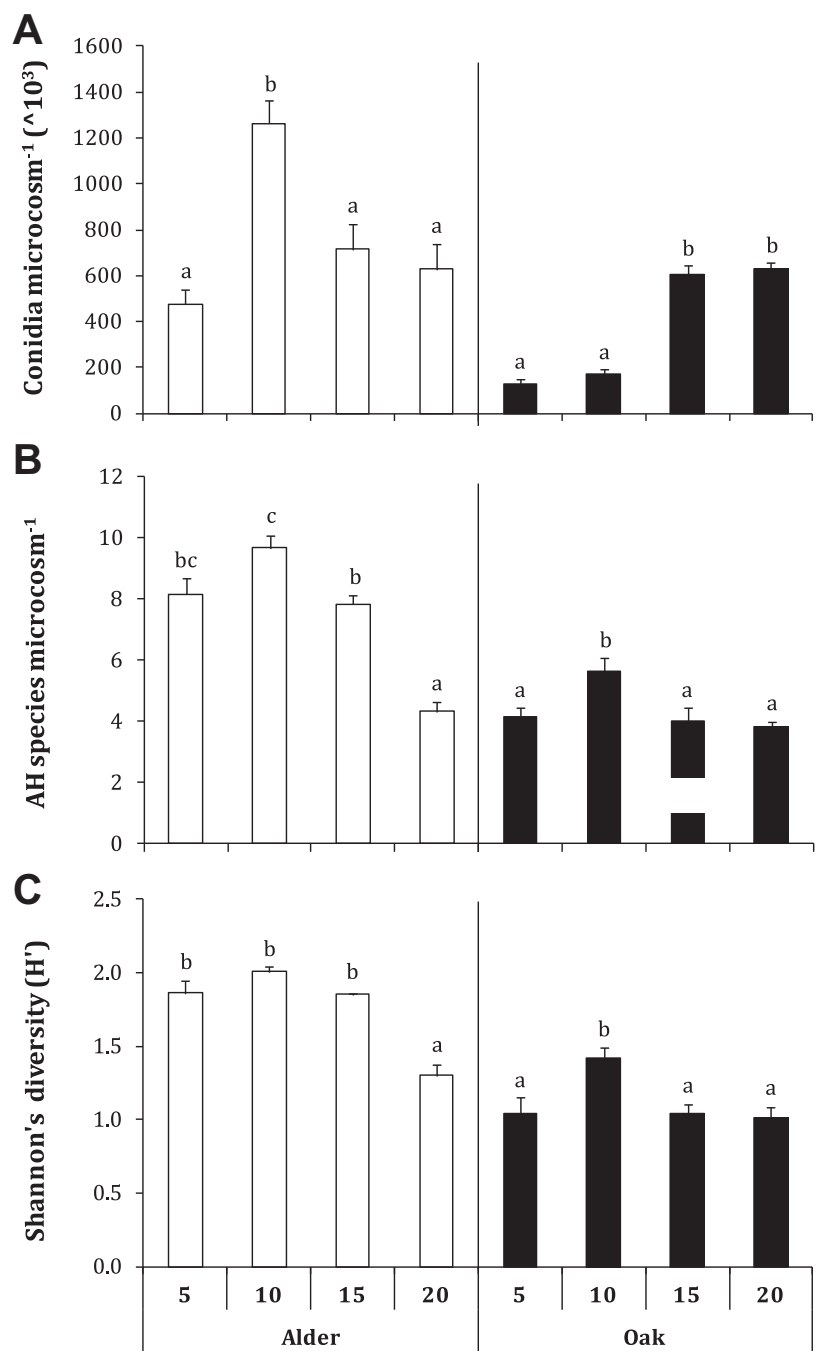

Temperature $\left({ }^{\circ} \mathrm{C}\right)$

Fig 2 - (A) Total number of conidia produced, (B) cumulative species richness per microcosm and (C) corresponding mean Shannon's diversity index, associated with alder and oak leaf discs incubated in microcosms for $56 \mathrm{~d}$ at 5, 10, 15 and $20{ }^{\circ} \mathrm{C}$ (mean $\pm \mathrm{SE}$; $n=6)$. 
$P=0.001$; Fig 2C). Flagellospora curvula and Alatospora acuminata were the major producers of spores at $10{ }^{\circ} \mathrm{C}$ (Fig 3A). A. acuminata, as the dominant fungal species at lower temperatures, tended to be replaced by Triscelophorus acuminatus and Tetrachaetum elegans over the gradient of temperature (Fig 3A).

In oak, the total number of spores was significantly higher at 15 and $20{ }^{\circ} \mathrm{C}$ (one-way ANOVA, $F_{3,20}=110.669$, $P<0.001$; Tukey's test, $P<0.001$; Fig 2A). However, as in alder, the total number of species and diversity $\mathrm{H}^{\prime}$ were higher at $10{ }^{\circ} \mathrm{C}$ than at the other temperatures (one-way ANOVA, $F_{3,20}=5.704, P=0.005$ and $F_{3,20}=4.221, P=0.018$, respectively; Fig $2 \mathrm{~B}, \mathrm{C})$. Flagellospora curta was the main contributor to the total conidia production at all temperatures in oak (>80 \%; Fig 3B).

The aquatic hyphomycete assemblages associated with the two leaf species, determined from conidial counts, were significantly affected by temperature (one-way ANOSIM, alder: $R=0.904, P=0.001$; oak: $R=0.345, P=0.001$; Fig $4 A, B$ ). In alder, the fungal communities at all temperatures were $<75 \%$ similar to each other, while the assemblage at $20{ }^{\circ} \mathrm{C}$ similarity was $<55^{\circ} \%$ (Fig $4 \mathrm{~A}$ ). The composition of oak fungal communities was consistently affected by temperature, and the general similarity among temperatures was $>75 \%$ (Fig 4B). An analysis of all the data (from alder and oak leaves) in a combined multidimensional analysis indicated that the
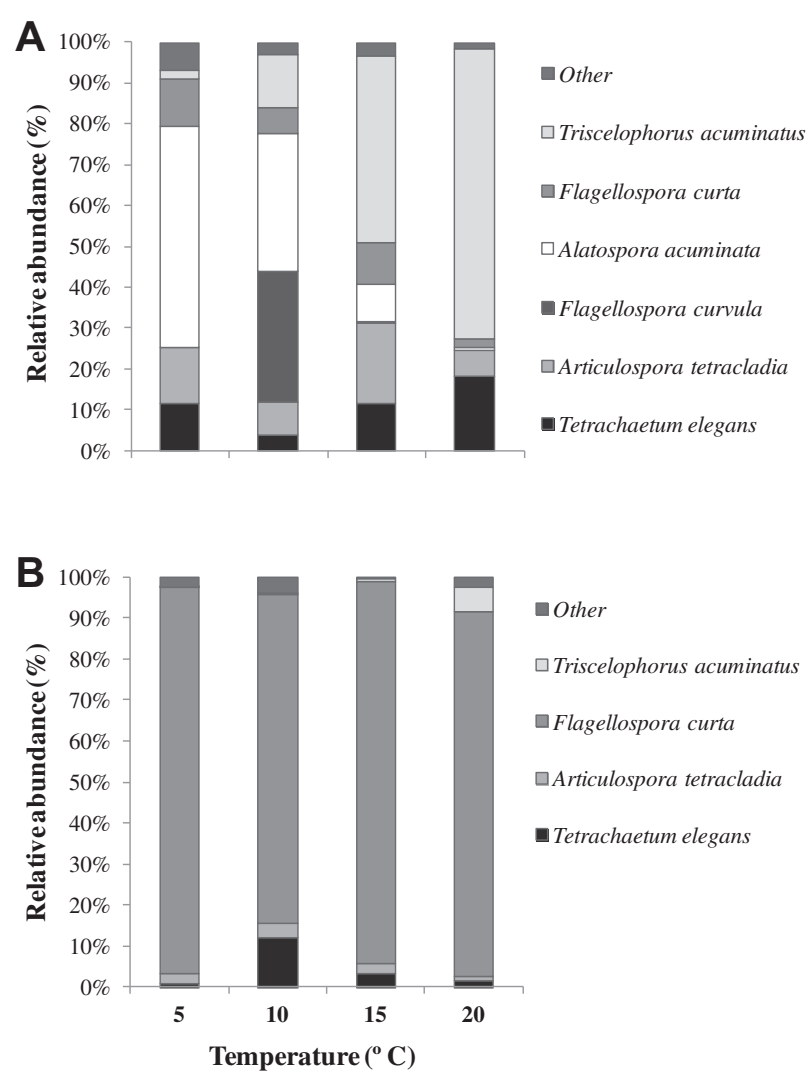

Fig 3 - Mean relative abundances (\%) of dominant hyphomycetes species from (A) alder and (B) oak leaf discs incubated in microcosms for $56 \mathrm{~d}$ at 5, 10, 15 and $20^{\circ} \mathrm{C}$ (mean \pm SE; $n=6)$.
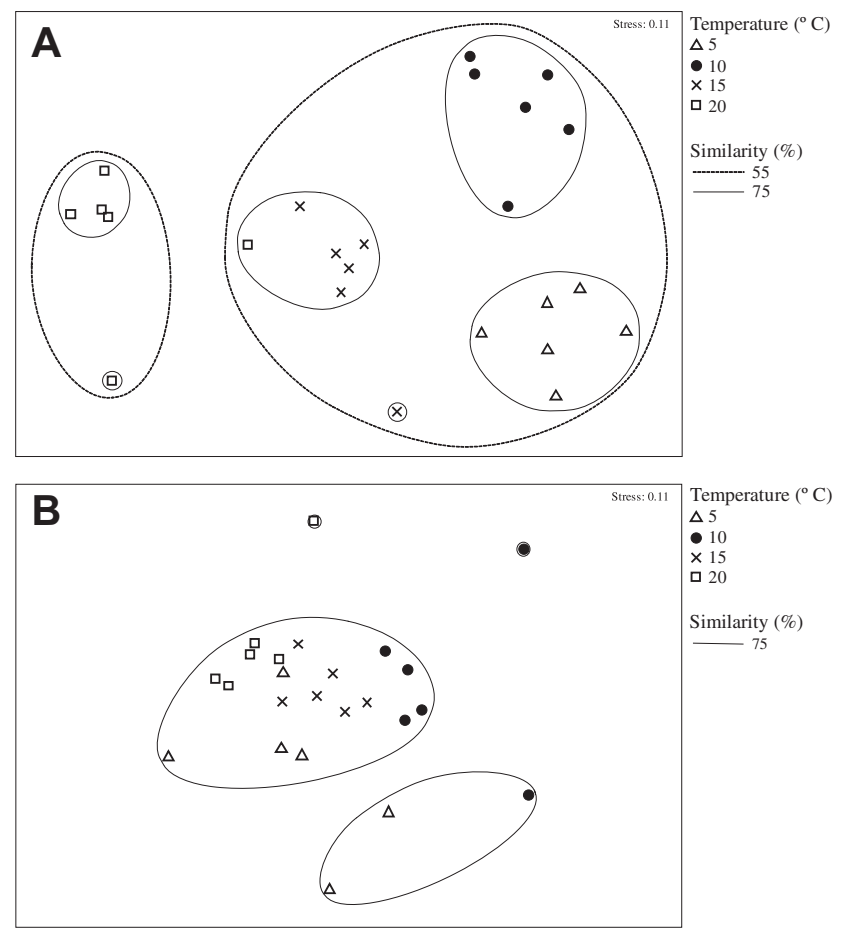

Fig 4 - Non-metric Multidimensional Scaling (NMDS) with overlay of correspondent cluster analysis, of samples of (A) alder and (B) oak fungal communities exposed to 5, 10, 15 and $20{ }^{\circ} \mathrm{C}$ for $56 \mathrm{~d}$ in microcosms, based on Bray-Curtis similarity matrix of relative abundances of aquatic hyphomycete conidia.

fungal community structure was more affected by the substratum quality than by temperature (two-way ANOSIM, by leaf species: $R=0.999, P=0.001$; Fig 5). Moreover, aquatic hyphomycete assemblages in alder leaf litter seemed to be more sensitive to temperature than when associated with oak (two-way ANOSIM, by temperature: $R=0.625, P=0.001$; Fig 5).

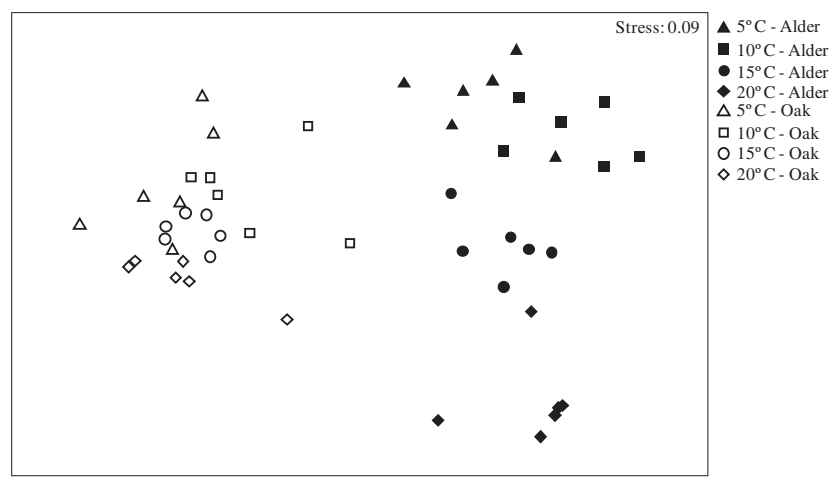

Fig 5 - Non-metric Multidimensional Scaling (NMDS) of fungal communities on (A) alder and (B) oak exposed to 5, 10,15 and $20{ }^{\circ} \mathrm{C}$ for $56 \mathrm{~d}$ in microcosms, based on Bray-Curtis similarity matrix of relative abundances of aquatic hyphomycete conidia. 


\section{Discussion}

In this study we showed that the quality of leaf substratum overrules temperature as determinants of microbial decomposition, at least for the range of temperatures and for the leaf species tested. Substratum properties have long been shown to control decomposition of organic matter and to be reliable indicators of leaf litter decomposition rates (e.g. Cornelissen et al., 1999; Bakker et al., 2011). In agreement with previous studies, oak and alder leaves seem to differ in their susceptibility to conidia settlement (Dang et al., 2007; Kearns and Bärlocher, 2008), mycelial mechanical invasion (Canhoto and Graça, 1999) and also fungal mediated enzymatic decomposition (Gessner et al., 2007). Dissimilar chemical composition, mainly in terms of the concentration of secondary compounds (e.g. polyphenols) and the presence/absence of a thick cuticle (determining, along with lignin, leaf toughness), may have controlled a priori the fungal imprint, the degradative potential of fungal species (Gessner and Chauvet, 1994; Canhoto and Graça, 1996) and the establishment of distinct fungal assemblages.

In oak decomposition, carbon mineralization and fungal conidia production generally increased with temperature, which is in line with the relationship between the carbon recalcitrance and temperature sensitivity found in terrestrial systems (Conant et al., 2008). Nonetheless, in a comparable study under laboratory conditions, Fernandes et al., (2012) did not find a significant effect of an increase of $8{ }^{\circ} \mathrm{C}$ on oak decomposition, sporulation rates or fungal diversity.

In contrast to oak, the changes in water temperature did not affect the carbon released or the decomposition rates of alder leaves. This was not expected considering previous microcosm approaches with natural (Fernandes et al., 2009, 2012) or manipulated aquatic hyphomycete communities (Dang et al., 2009; Ferreira and Chauvet, 2011a,b), where an increment of $5-8{ }^{\circ} \mathrm{C}$ stimulated microbial decomposition in alder. Besides differences in experimental conditions among experiments (e.g. the leaching and conditioning period in the stream), we cannot rule out intraspecific variations in leaf chemistry and physical properties. Indeed, large intraspecific variability in leaf quality due to environmental conditions and genetic variation has been demonstrated (e.g. LeRoy et al., 2007, 2012; Lecerf and Chauvet, 2008), which may modulate temperature effects.

In our study, the maximum fungal biomass on oak leaves was constant among temperatures; however, the same fungal biomass was more efficient in breaking down substrates and invested more in reproduction at higher temperatures, as expected from the relationship between metabolism and temperature (Friberg et al., 2009; Bergfur and Friberg, 2012). In alder, the fungal biomass tended to decrease over the temperature gradient. Again, however, the efficiency increased with temperature, as the lower biomass at the highest temperature resulted in decomposition rates similar to the other temperatures.

Alder sporulation peaked at $10^{\circ} \mathrm{C}$ (the stream temperature during the incubation period), which is consistent with Fernandes et al. (2009, 2012), but contrary to other studies, where sporulation increased at higher temperatures (i.e. $15^{\circ} \mathrm{C}$ ) on leaves inoculated with manipulated fungal assemblages (e.g. Ferreira and Chauvet, 2011a). Although the reason for such discrepancies needs further investigation, it seems possible that specific responses are related to the composition of the communities and with the individual response of fungal species to temperature changes. If the environmental temperature departs from the species' optimum, its fitness, particularly its reproductive output, may decline (Chauvet and Suberkropp, 1998).

Significant shifts in species richness and community structure occurred across temperatures in both species. The maximum number of fungal species, on oak and alder leaves, was found at $10{ }^{\circ} \mathrm{C}$, the closest to the temperature in the incubation stream. It is reasonable to assume that fungal taxa initially colonizing the leaves were acclimatized to the ambient temperature in the stream (Rajashekhar and Kaveriappa, 2000). In alder, fungal diversity decreased with temperatures $>10^{\circ} \mathrm{C}$. However, in oak there were no differences in diversity across higher temperatures (i.e. 15 and $20^{\circ} \mathrm{C}$ ). This result is consistent with previous reports by Fernandes et al. (2012) where a significant lower diversity was observed at $24^{\circ} \mathrm{C}$ in comparison with $16{ }^{\circ} \mathrm{C}$ in alder, even though no significant differences were observed in oak leaves.

Not only did fungi differ between leaves but within leaves, there were differences across temperatures, particularly in alder. Several studies, mainly dealing with the effects of global warming on the activities of decomposers, have previously described aquatic hyphomycete species as sensitive to changes in water temperature (Bärlocher et al., 2008; Dang et al., 2009; Fernandes et al., 2009; Ferreira and Chauvet, 2011a,b). For example, F. curvula and Articulospora tetracladia have been associated with low, and T. elegans with high, temperatures (Chauvet and Suberkropp, 1998; Fernandes et al., 2009; Ferreira and Chauvet, 2011a,b). In this study fungal assemblages on alder were clearly different across temperatures, with spores of A. acuminata being more abundant at the lower range of the temperatures tested; T. acuminatus and $T$. elegans were clearly dominant at warmer temperatures. Considering that the initial inoculum and the four temperatures were the same for both leaf types, the ordination revealed that the leaf substratum is more important than temperature for fungal community structure. Species such as F. curvula, A. acuminata, Tricladium splendens and even A. tetracladia were more frequent on alder and hardly seen on oak. These findings are in agreement with reports suggesting substratum specificity by fungi (Gulis, 2001; Ferreira et al., 2006).

Despite the differences in fungal assemblages on alder, the decomposition of these leaves was maintained over a wide temperature regime as previously indicated. Assuming that spore counts are proportional to fungal diversity and species abundance, the results suggest functional redundancy of fungal communities across temperatures. In contrast, on oak, F. curta was present at all temperatures tested and differences in community structure (as judged by MDS on conidia counts) were more consistent across temperatures. Three nonexclusive explanations may explain these results: F. curta (a) is ubiquitous and its importance to leaf litter decomposition throughout the year in temperate Portuguese streams is already known (Pascoal et al., 2005; Duarte et al., 2009; 
Gonçalves and Canhoto, 2009); (b) has a known optimum at $20^{\circ} \mathrm{C}$, which was the highest temperature tested here; (c) took advantage of a reduction of the antagonistic interactions among aquatic hyphomycetes (as previously reported for this species by Duarte et al. (2006)), through the colonization period or during early colonization in the stream. In this study, spore production was used to estimate the diversity of the community established on colonized leaves (Duarte et al., 2012); such an approach may underestimate the number of fungal taxa colonizing both leaf species (Nikolcheva et al., 2003, 2005). Further studies using molecular approaches (e.g. denaturing gradient gel electrophoresis) are advisable as they may add accuracy to the evaluation of fungal and bacterial diversity on decomposing substrata such as alder and oak (Krauss et al., 2011; Nikolcheva et al., 2003, 2005).

In conclusion, our results suggest that both substratum and temperature are important drivers of fungal mediated litter decomposition, with substratum quality being more important than temperature. The effect of temperature was more pronounced in the more recalcitrant oak leaves colonized by less diverse fungal communities. Although we used alder and oak as contrasting test-species, a large number of leaves, with a wide range of traits, are usually found in temperate streams. Little is known of their functional response under global warming scenarios or changes in thermal regime promoted by forestry practices. Cascading effects are expected considering the selective feeding by shredders on the leaffungal consortia (Canhoto and Graça, 2008). Our results indicate that leaf litter traits should be considered when riparian forests are managed with the objective of protecting stream communities against climate change.

\section{Acknowledgments}

We thank Alberto Blanco for the help and assistance with the determination of the total microbial respiration and Felix Bärlocher for comments on an earlier version of the manuscript. This study was supported by the European Regional Development Fund (ERDF) through the COMPETE - Operational Factors of Competitiveness Program (POFC-COMPETE) and national funds through FCT - Foundation for Science and Technology, under the project "Predicting the effect of global warming on stream ecosystems" (FCT Ref: PTDC/CLI/67180/ 2006; COMPETE Ref: FCOMP-01-0124-FEDER-007112). The Portuguese Foundation for Science and Technology also supported ALG (reference SFRH/BD/47089/2008).

\section{R E F E R E N C E S}

Abelho, M., 2001. From litterfall to breakdown in streams: a review. The Scientific World 1, 656-680.

Allan, J.D., Castillo, M.M., 2007. Stream Ecology: Structure and Function of Running Waters, second ed. Chapman and Hall, New York, USA.

Bakker, M.A., Carreño-Rocabado, G., Poorter, L., 2011. Leaf economics traits predict litter decomposition of tropical plants and differ among land use types. Functional Ecology 25, 473-483.

Bärlocher, F., Kebede, Y.K., Gonçalves, A.L., Canhoto, C., 2013. Incubation temperature and substrate quality modulate sporulation by aquatic hyphomycetes. Microbial Ecology 65 . http://dx.doi.org/10.1007/s00248-013-0202-7.

Bärlocher, F., Seena, S., Wilson, K.P., Williams, D.D., 2008. Raised water temperature lowers diversity of hyporheic aquatic hyphomycetes. Freshwater Biology 53, 368-379.

Baldy, V., Chauvet, E., Charcosset, J.-Y., Gessner, M.O., 2002. Microbial dynamics associated with leaves decomposing in the mainstem and floodplain pond of a large river. Aquatic Microbial Ecology 28, 25-36.

Bergfur, J., Friberg, N., 2012. Trade-offs between fungal and bacterial respiration along gradients in temperature, nutrients and substrata: experiments with stream derived microbial communities. Fungal Ecology 5, 46-52.

Canhoto, C., Graça, M.A.S., 1996. Decomposition of Eucalyptus globulus leaves and three native leaf species (Alnus glutinosa, Castanea sativa and Quercus faginea) in a Portuguese low order stream. Hydrobiologia 333, 79-85.

Canhoto, C., Graça, M.A.S., 1999. Leaf barriers to fungal colonization and shredders (Tipula lateralis) consumption of decomposing Eucalyptus globulus. Microbial Ecology 37, 163-172.

Canhoto, C., Graça, M.A.S., 2008. Interactions between fungi (aquatic hyphomycetes) and invertebrates. In: Sridhar, K.R., Bärlocher, F., Hyde, K.D. (Eds.), Novel Techniques and Ideas in Mycology. Fungal Diversity Research Series. University of Hong Kong, pp. 205-325.

Chauvet, E., Suberkropp, K., 1998. Temperature and sporulation of aquatic hyphomycetes. Applied Environmental Microbiology 64, 1522-1525.

Clarke, K.R., Gorley, R.N., 2001. Primer v5: User Manual/Tutorial. Primer-E Ltd., Plymouth, UK.

Conant, R.T., Drijber, R.A., Haddix, M.L., Parton, W.J., Paul, E.A., Plante, A.F., Six, J., Steinweg, J.M., 2008. Sensitivity of organic matter decomposition to warming varies with its quality. Global Change Biology 14, 868-877.

Conant, R.T., Ryan, M.G., Ågren, G.I., Birge, H.E., Davidson, E.A., Eliasson, P.E., Evans, S.E., Frey, S.D., Giardina, C.P., Hopkins, F.M., Hyvönen, R., Kirschbaum, M.U.F., Lavallee, J.M., Leifeld, J., Parton, W.J., Steinweg, J.M., Wallenstein, M.D., Wetterstedt, J.Å.M., Bradford, M.A., 2011. Temperature and soil organic matter decomposition rates - synthesis of current knowledge and a way forward. Global Change Biology 17, 3392-3404.

Cornelissen, J.H.C., Pérez-Harguindeguy, N., Díaz, S., Grime, G.P., Marzano, B., Cabido, M., Vendramini, F., Cerabolini, B., 1999. Leaf structure and defence control litter decomposition rate across species and life forms in regional floras on two continents. New Phytologist 143, 191-200.

Dang, C.K., Gessner, M.O., Chauvet, E., 2007. Influence of conidial traits and leaf structure on attachment success of aquatic hyphomycetes on leaf litter. Mycologia 99, 24-32.

Dang, C.K., Schindler, M., Chauvet, E., Gessner, M.O., 2009. Temperature oscillation coupled with fungal community shifts can modulate warming effects on litter decomposition. Ecology 90, 122-131.

Duarte, S., Cássio, F., Pascoal, C., 2012. Denaturing gradient gel electrophoresis (DGGE) in microbial ecology: insights from freshwaters. In: Lazinica, A. (Ed.), Gel Electrophoresis/Book 1, ISBN 979-953-307-474-9, pp. 173-196.

Duarte, S., Pascoal, C., Cássio, F., Bärlocher, F., 2006. Aquatic hyphomycete diversity and identity affect leaf litter decomposition in microcosms. Oecologia 147, 658-666.

Duarte, S., Pascoal, C., Cássio, F., 2009. Functional stability of stream-dwelling microbial decomposers exposed to copper and zinc stress. Freshwater Biology 54, 1683-1691. 
Fernandes, I., Uzun, B., Pascoal, C., Cássio, F., 2009. Responses of aquatic fungal communities on leaf litter to temperature change events. International Review of Hydrobiology 94, 410-418.

Fernandes, I., Pascoal, C., Guimarães, H., Pinto, R., Sousa, I., Cássio, F., 2012. Higher temperature reduces the effects of litter quality on decomposition by aquatic fungi. Freshwater Biology 57, 2306-2317.

Ferreira, V., Chauvet, E., 2011a. Synergistic effects of water temperature and dissolved nutrients on litter decomposition and associated fungi. Global Change Biology 17, 551-564.

Ferreira, V., Chauvet, E., 2011b. Future increase in temperature more than decrease in litter quality can affect microbial litter decomposition in streams. Oecologia 167, 279-291.

Ferreira, V., Gulis, V., Graça, M.A.S., 2006. Whole-stream nitrate addition affects litter decomposition and associated fungi but not invertebrates. Oecologia 149, 718-729.

Friberg, N., Dybkjaer, J.B., Olafsson, J.S., Gislason, G.M., Larsen, S.E., Lauridsen, T.L., 2009. Relationships between structure and function in streams contrasting in temperature. Freshwater Biology 54, 2051-2068.

Geraldes, P., Pascoal, C., Cássio, F., 2012. Effects of increased temperature and aquatic fungal diversity on litter decomposition. Fungal Ecology 5, 734-740.

Gessner, M.O., Chauvet, E., 1993. Ergosterol-to-biomass conversion factors for aquatic hyphomycetes. Applied Environmental Microbiology 59, 502-507.

Gessner, M.O., Chauvet, E., 1994. Importance of stream microfungi in controlling breakdown rates of leaf litter. Ecology 75, 1807-1817.

Gessner, M.O., Chauvet, E., Dobson, M., 1999. A perspective on leaf litter breakdown in streams. Oikos 85, 377-383.

Gessner, M.O., Gulis, V., Kuehn, K.A., Chauvet, E., Suberkropp, K., 2007. Fungal decomposers of plant litter in aquatic ecosystems. In: Kubicek, C.P., Druzhinina, I.S. (Eds.), The Mycota: A Comprehensive Treatise on Fungi as Experimental Systems for Basic and Applied Research, Environmental and Microbial Relationships, second ed., vol. IV. Springer-Verlag, Berlin, Germany, pp. 301-324.

Gessner, M.O., Swan, C.M., Dang, C.K., McKie, B.G., Bardgett, R.D., Wall, D.H., et al., 2010. Diversity meets decomposition. Trends in Ecology \& Evolution 25, 372-380.

Goering, H.K., Van Soest, P.J., 1970. Forage Fiber Analysis (Apparatus, Reagents, Procedures and Some Applications). USDA Agricultural Handbook No. 379.

Gonçalves, A.L., Canhoto, C., 2009. Decomposition of eucalypt and alder mixtures: responses to variation in evenness. Fundamental and Applied Limnology/Archive für Hydrobiologie 173, 293-303.

Graça, M.A.S., Bärlocher, F., Gessner, M.O., 2005. Methods to Study Litter Decomposition. A Practical Guide. Springer, The Netherlands.

Gulis, V., 2001. Are there any substrate preferences in aquatic hyphomycetes? Mycological Research 105, 1088-1093.

Gulis, V., Ferreira, V., Graça, M.A.S., 2006. Stimulation of leaf litter decomposition and associated fungi and invertebrates by moderate eutrophication: implications for stream assessment. Freshwater Biology 51, 1655-1669.

Kearns, S.G., Bärlocher, F., 2008. Leaf surface roughness influences colonization success of aquatic hyphomycete conidia. Fungal Ecology 1, 13-18.

Krauss, G.J., Solé, M., Krauss, G., Schlosser, D., Wesenberg, D., Bärlocher, F., 2011. Fungi in freshwaters: ecology, physiology and biochemical potential. FEMS Microbiology Reviews 35, 620-651.

Lecerf, A., Chauvet, E., 2008. Intraspecific variability in leaf traits strongly affects alder leaf decomposition in a stream. Basic and Applied Ecology 9, 598-605.

Lecerf, A., Dobson, M., Dang, C.K., Chauvet, E., 2005. Riparian plant species loss alters trophic dynamics in detritus-based stream ecosystems. Oecologia 146, 432-442.

Lecerf, A., Risnoveanu, G., Popescu, C., Gessner, M.O., Chauvet, E., 2007. Decomposition of diverse litter mixtures in streams. Ecology 88, 219-227.

LeRoy, C.J., Whitham, T.G., Wooley, S.C., Marks, J.C., 2007. Withinspecies variation in foliar chemistry influences leaf-litter decomposition in a Utah river. Journal of the North American Benthological Society 26, 426-438.

LeRoy, C.J., Wooley, S.C., Lindroth, R.L., 2012. Genotype and soil nutrient environment influence aspen litter chemistry and instream decomposition. Freshwater Science 31, 1244-1253.

Nikolcheva, L.G., Cockshutt, A.M., Bärlocher, F., 2003. Determining diversity of freshwater fungi on decomposing leaves: comparison of traditional and molecular approaches. Applied and Environmental Microbiology 69, 2548-2554.

Nikolcheva, L.G., Bourque, T., Bärlocher, F., 2005. Fungal diversity during initial stages of leaf decomposition in a stream. Mycological Research 109, 246-253.

Pascoal, C., Marvanová, L., Cássio, F., 2005. Aquatic hyphomycete diversity in streams of northwest Portugal. Fungal Diversity 19, 109-128.

Rajashekhar, M., Kaveriappa, K.M., 2000. Effects of temperature and light on growth and sporulation of aquatic hyphomycetes. Hydrobiologia 441, 149-153.

Suberkropp, K., 2001. Fungal growth, production, and sporulation during leaf decomposition in two streams. Applied and Environmental Microbiology 67, 5063-5068.

Tellinghuisen, J., 2001. Statistical error propagation. The Journal of Physical Chemistry A 105, 3917-3921.

Webster, J.R., Benfield, E.F., 1986. Vascular plat breakdown in freshwater ecosystems. Annual Review of Ecology and Systematics 17, 567-594.

Woodward, G., Perkins, D.M., Brown, L.E., 2010. Climate change and freshwater ecosystems: impacts across multiple levels of organization. Philosophical Transactions of the Royal Society B 365, 2093-2106.

Young, J.C., 1995. Microwave-assisted extraction of the fungal metabolite ergosterol and total fatty acids. Journal of Agricultural and Food Chemistry 43, 2904-2910.

Zar, J.H., 1999. Biostatistical Analysis, fourth ed. Prentice-Hall, Englewood Cliffs, NJ. 